48. Cebhard. Ueber die vom Oberflächenepithel ausgehenden Carcinomformen des Uteruskörpers so wie über den Hornkrebs des Cavum Uteri (Zeitschr. f. Geb. u. Gyn. XXIV B. I Н.). 0 формахъ рака тьла матки, исходящихъ изъ поверхностнаго эпителія, и о конкроидђ маточной полости.

Изсльдованіями Ruge п Veit'a установлены дв' формы карциномъ слизистой оболочкі полости матки (1-я начинающаяся съ расширенія просвњта железъ, выполненныхъ эпителіальными элементами, и 2-я начннающаяся съ усиленнаго разростанія самихъ железъ), существованіе которыхъ подтверждено и другими изсльдователями, и қоторыя многими считаются за единственныя формы рака, встрьчающагося въ маткь. Piering первый описаль случай первичнаго канкрошда полости, развившагося на слизистой оболочкь маткп, всецьло покрытої плоскимъ эпителіемъ, и давшаго метастазы на пейку. Замьна цилиндрнческаго эпителія плоскимъ въ маткь вообще наблюдается крайне рьдко, по мньнію G.; при этомъ надо строго отличать два разные процесса: 1) доброкачественное распространеніе плоскаго эпитедія по поверхности съ ороговьніемъ верхняго слоя всльдствіе химическихъ, механическихъ, п, можеть быть, микотпчелкихъ раздраженій и 2) разростаніе плосскаго эпптелія на поверхности тьла и шейки сь наклонностью давать отростки въ глубину ткани; въ этихъ случаяхъ кльтки эпителія находятс⿰ь въ состояніп то регрессивнаго, то прогрессивнаго метаморфоза. Это уже злокачественный раковый шроцессъ, хотя железы не принимають въ немъ учдстія. Повидимому данная форма, очень рьддко встрђчающаяся, не развнвается первично, а распространяется по поверхности всей слизистой оболочки, исходя пзъ первичнаго раковаго очага. Сюда относится тщательно пзсльдыванный случап̆ Benckiser'a; автору танже прпшлось наблюдать подобныі случай при изсльдованіи присланныхь ему выскобленныхь кусочковъ слгзпстой оболочки полости. Второй же случай G., подобно случаю Piering'a, носпть характеръ чистаго канкроида; случай G. отличается тьмъ, что представляетъ псключительно ракъ тьыла матки безъ всякаго пораженія пейкн. Больная, 66 л.,съ prolapsus vaginae и gonorrhoea ста́ла страдать нровотеченіями; микроскопическое изсльдованіе выскобленныхъ кусочковъ слизистої оболочки указало на существованіе канкроида, всльдствіе чего сдылана экстирпація матки. Найденъ стенозъ внутренняго зъва, руотеtra и раковыя разращенія в'ь дн'ь ил боковыхъ стьнкахъ; микроскопическое изсльдованіе дало сльдующую картину: среди скудной основы изъ вытянутыхъ соединительно-тканныхъ кльтокъ, пронизанной островкамп изъ круглыхъ элементовъ, проходять цаугиплоско-эпителіальныхъ кльтокъ;ть изъ нихъ, которыя расподожены блше

ванія (Jinpfinelustase) ракъ влагалища и уре тры, но етроенію тож, детвенный съ первичным' ракомъ тьла матки (Fischer, «Zur Entstehungsweise secundärer Scheidenknoten bei primärern Gebämutterkrebs» Zeitschrift fuir Geburts. und GynäkoI., Band. XXI, s. 185). Къ этой же категоріи метастазовъ иричисляеть Kaltınbach и свой случай рака внутренняго отверстія уретры, происшедшій оть рака тьлла матки. (Berlin. Klin. Wochenschrift, 1889, 샤 18). 
жь середины, отличаются большеї велпчної, заключають въ себъ большія овальныя ядра, пныя по ньсколько; во многихъ замъчается питозъ й многополюсныя веретенообразныя фнгурн; въ центрь плоскоэпителіальныхъ островковъ-луковичныя канкроидныя образованія изъ большей частью безъядерныхъ кльтокъ; на границ' между мускулатурой матки и новообразованіезъ лежить слой, инфильтрированный мелко-кльточными элементами, мъстами переходящій въ нагноеніе. На поверхностп, не занятой разращеніями, нигдь не удалось найти сльдовъ- эпителія слизистой оболочки, такъ-какъ вся поверхность оказалась изъязвленноі, пюэтому въ данномъ случањ нельзя было доказать первоначальнаго замьщенія цилиндрнческаго эпителія пдоскимъ.

\section{А. Пекарская.}

49. D-r Janvrin. The palliative treatement of such cases of cancer of the uterus and its annexa, as are notamenable to radical operative measures (The New-Jork Medical Journal 1892, Vol. LVI, Nㅡ 28). Палліативное льченіе тьхъ случаевъ рака матки и ея придатковъ ноторые не поддаются радикальнымъ оперативнымъ м Бропріятіямъ.

Авторъ горячо выражаеть желаніе, чтобы вь предмъстіяхъ каждаго большаго города были учреждены особыл санаторіи, назначенныя для неизльчимыхъ больныхъ женщинъ, страдающихъ ракомъ матки и придатковъ, гдъ свьжії воздухъ, полный просторъ и вообе вадлежащая обстановка помогалибы врачу въ его тлжелой задачђ. Мъстное льченіе должно состоять въ энергичномъ прит'ьевіи острої ложечки, глубоко проникающеї въ самый центрь инфильтраціи. Если во время операціи ложечка тьмъ или другимъ путемь попадаетъ въ полость брюшины, то для предупреждені́я выпаденія кишекь вкладываютъ антисептическія губки съ привязанными къ нимъ нитками. Кровотеченіе предоставляется самому себъ, или оно можеть быть задерживаемо горячими душами, употребленіемъ насыщеннаго раствора таннина, примьненіемъ термокаутера, а въ особенно упорныхъ случаяхъ временнымъ тампонированіемъ влагалища. Когда уже прекратилось всякое истеченіе, и окружающія части вытерты досуха, операціонная поверхность выстплается гигроскопическими компрессами (pledgets of absorbcut cotton), и пршжигается $50 \%$ растворомъ хлористаго цннка, предварительно покрывшп выпавшія кишки іодоформенной марлей. Чрезъ 24 часа компрессы и марля удаляғотя, полость промывается 1:5000 растворомъ сулемы, вытирается досуха п посышается порошкомъ іодоформа. Струпья оть хлоршстаго цинка чрезъ недълю обынновенно отваливағотся, оставляя чистую поверхность. Авторь особенно напираеть на прегращеніе всякихъ истеченій и полное вытираніе досуха операціонной поверхности прежде, чьмъ приступить къ прижиганію хлористымь цинкомъ, такъ какъ результаты получаются тогда гораздо лучшіе. Препараты мышьяка и жельза даются внутрь, какъ общетоническія средства, но без'ь -всякой надежды на ихъ специфическое мъстное дыйствіе.

B. Каплянскій. 